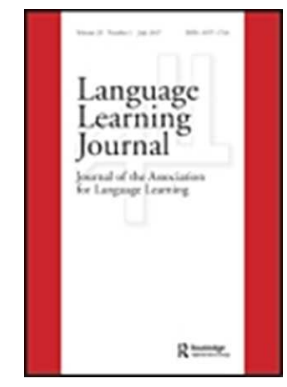

The impact of learning Latin on primary school pupils: Review of existing data

\begin{tabular}{|r|l|}
\hline Journal: & The Language Learning Journal \\
\hline Manuscript ID & RLLJ-2015-0113.R2 \\
\hline Manuscript Type: & Original Paper \\
\hline Keywords: & Latin, literacy, review, foreign languages \\
\hline & \\
\end{tabular}

SCHOLARONE ${ }^{\text {IM }}$

Manuscripts 


\title{
The impact of learning Latin on school pupils: Review of existing data
}

\begin{abstract}
This article reviews a century of US data on the impact of learning Latin and explores to what extent the collected findings demonstrate Latin can play a vital role in improving pupils' educational attainments, particularly L1, MFL, and cognitive development. Contextualizing the data allows us to explore their aims, findings, and shortcomings. We argue that, while the collated data do provide significant evidence for the beneficial impact of learning Latin on L1 development of English native speakers, evidence for impact on MFL and cognitive development is less substantial. It is therefore pivotal to acknowledge that these data must therefore be applied with caution, as a meaningful starting point for new research based on modern methodologies.
\end{abstract}

Keywords: Latin; literacy; review; foreign languages

\section{Latin, ideology and pedagogy}


Latin is not a neutral subject for either a school to teach or a pupil to study. Shaped by centuries of association with the ideological elite - such as the British Empire or the Catholic Church ${ }^{1}$ - Latin has become a symbol of contradictions. On the one hand, it is praised as an aspirational subject that opens doors to modern languages and European history. On the other, it is attacked for being a tool of social exclusion and a difficult dead language without practical application. Latin has indeed divided opinion for at least a century, since it finally ceased to be the lingua franca of the Western world, and the battle concerning its value for young people's education continues among teachers and governments. This has currently led to a situation of extremes: while the subject is marginalized in some educational curriculums which are focused on STEM practicality (such as in France and Wales), other governments are placing it centre stage (such as the Netherlands and Wallonia).

Because of the ideologically loaded status of Latin, teachers have long had to or felt the need to - justify the existence of Latin on the curriculum. Approximately a century ago, this led to research exploring the quantifiable value of Latin for young people's education, particularly with regard to linguistic and cognitive benefits. Research set out to demonstrate the following three hypotheses regarding the advantages of studying Latin, based on circumstantial evidence reported by teachers. ${ }^{2}$

First, since Latin lies at the root of $60 \%$ of English words, studying it will have a beneficial impact on development of native speakers' English vocabulary in specific and language skills in general, more so than studying a modern foreign language. In an article expounding the virtues of studying Latin, Colligan (1944: 15) argued that 'High school students should be led to recognize that so long as the English language lives the Latin language cannot die, and that the practical values of Latin thus equal or exceed those of any course in the secondary school curriculum'. Secondly, since Latin lies at 
the root of modern Romance languages and has impacted the development of Germanic and even Celtic languages, ${ }^{3}$ studying Latin (first) will have a beneficial impact on the acquisition of modern foreign languages. In a 2013 article in The Guardian, Livingstone argues that 'according to the same principle that your great-grandfather had children and grand-children and great-grandchildren, learning a language that occupies a place farther up the family tree will mean that younger languages will have grown up out of it'. Thirdly, since Latin is a logical, almost mathematical language and is considered the 'prototype of phonemic writing' (Coulmas (1989: 93)) with high correspondence between spelling and pronunciation, its study will have a positive impact on general cognitive skills, beyond languages. As Morgan (2010: 6) posits in a report written by the Politeia think-tank concerning the potential to offer Latin at primary school level in the UK, Latin is 'the maths of the Humanities: a training in analytical thought for which no preparation is required'.

Since 1915, fifty US tests have aimed to gauge the impact of learning Latin on pupils with regard to one or more of these premises. Only two studies from outside the US currently exist: ${ }^{4}$ one from Germany and one from the UK. That the data derive primarily from the US may be explained largely by the financial impetus that the two major US Classics organisations have long provided for quantitative testing. ${ }^{5}$

The findings of the US tests are still mentioned unreservedly as clear evidence in favour of the teaching of the subject by proponents of Latin. ${ }^{6}$ The positive findings, however, relate to Latin teaching in specific contexts, both historical, socio-economic and pedagogic. The aim of this article is therefore to review the findings of the US data by contextualizing the findings and methodologies of the studies. This will provide substantiation concerning the reliability of the past century of data, as well as a startingpoint for further research. 


\section{US research: Quantifying the value of learning Latin}

Assessing and synthesizing the existing US data is a complex task. First, it is possible to identify the majority of the evidence: to our knowledge, results of fifty US studies regarding the impact of Latin have been published since $1915 .^{7}$ Unpublished studies must exist, however, and it has been difficult to track the details particularly for the earlier evidence, so while this review aims to be extensive, it cannot claim to be complete. A list of all the studies in chronological order can be found in the Appendix.

Secondly, meta-analysis (collation of data from previous studies and re-analysis of the results) on the existing studies is impossible, since some of the data are no longer available. A systematic review - which identifies the evidence, selects studies based on eligibility criteria, assesses their quality, synthesizes and interprets findings, and provides an impartial summary - is equally impracticable. Most of the existing 1970s and 1980s studies would be insufficient in quality, not only because very little information is provided concerning the entire testing process, but also because the variables - such as aims, pupil age, extent of Latin instruction, testing method, pedagogic methodology, socio-economic context and others - are often withheld or summarized. ${ }^{8}$ With regard to the testing method, while the 1970/71 study in Philadelphia, for example, used the Iowa Test of Basic Skills (Mavrogenes 1977), the early 1970s test in Boston used a general vocabulary test as well as a test of vocabulary of Latin-derived words (Mavrogenes 1977); the 1975 Los Angeles study used the Comprehensive Test of Basic Skills (Masciantonio 1977); the 1981 Brooklyn study used the California Achievement Test (vocabulary and comprehension) (Fromchuck 1984); and the 1980s Illinois study used SATs and composition tests (Reinhardt 1983). Studies have also used different quantifiables, such as percentage, years, or points on a 
certain scale to determine pupil progress. Pedagogy ranged from traditional grammartranslation approach to the oral-aural approach, multisensory approach, and the reading approach. Comparing the various findings is thus challenging. Nevertheless, by performing a tentative retrospective review of the data and gathering evidence concerning specific outcomes, it is possible to distinguish prevailing correlations.

\section{Findings}

The strongest case can be made for the impact Latin has on increased linguistic skills in English native speakers (L1), both at primary and secondary school. The seminal study in this area, by Rudolph Masciantonio (1977), documents a number of local studies from the early 1970s. In Philadelphia, for example, 4,000 primary school children were given twenty minutes of Latin instruction per day during one school year, using the 'multisensory' approach (Masciantonio (1977: 376)). Pupils were assessed by means of the vocabulary part of the Iowa Test of Basic Skills to test their English vocabulary level: in comparison with the control group (pupil number not specified), those pupils who had studied Latin 'was one full year higher than the performance of matched control pupils' (Masciantonio (1977: 377)).

Around the same time, Judith LeBovit organised a similar programme of Latin in Washington D.C. high schools. Pupils who had studied one year of Latin were tested by means of the Comprehensive Test of Basic Skills and compared with not only with a control group without foreign language, but also with a control group who had studied four years of French or Spanish. Latin teaching was 'based on modern linguistic theory and typified by the oral-aural approach with special attention paid to word derivations and cultural background' (Sussman (1978: 346)). As Sussman (1978: 348) reports, the English reading scores of Latin pupils were 'significantly higher' - no level is specified 
- than those of both control groups, and the report particularly highlighted the 'positive transfer effect to the mastery of English reading skills' of Latin.

Similar findings regarding the impact of Latin learning on literacy skills of English native speakers abound from between 1015 and the 1990s, both at primary and secondary school level: Harris (1915), Gilliland (1922), Thorndike (1924), Douglas and Kittleson (1935), Josephina (1963), Lebovit (1967), Bowker (1975), Masciantonio (1977), Polsky (1986), Lafleur (1981 and 1985), Offenberg (1982), Townsley (1985), Barber (1986), Van Tassel-Baska (1987), Sparks (1996), and DeVane (1997) all report significant improvements in English vocabulary among Latin learners in comparison with control groups without a foreign language or with a modern foreign language. Similarly, Lebovit (1967), Cederstrom (1974), Masciantonio (1977), Polsky (1986), LaFleur (1981 and 1985) and Polsky (1986) report significant progress with regard to reading and comprehension in comparison with control groups. The degree of significance does differ, however - and indeed often the precise degree is omitted - but the findings are nevertheless substantial. There are outliers, such as Otis (1922), Miller and Briggs (1923) and Coxe (1924), which only testify to minor or insignificant differences. Yet considering the large number of tests over a large period of time, this minority of exceptions confirms the general trend. Interestingly, Polsky (1986: 77-83), Sparks et al. (1996), Ashe (1998) and Hill (2006: 50-67) report the particular use of Latin instruction for improving the English language skills of pupils with special educational needs. ${ }^{9}$

For the second hypothesis, that Latin prepares pupils for modern foreign language study - at least Romance and, to a lesser extent, Germanic and Celtic languages - because it has impacted on Western culture and languages for the past millennium, the evidence is 
more circumstantial. Findings such as those by LeBovit, LaFleur (1981 and 1985) and Wiley (1985), which compare the L1 skills of Latin students to that of modern foreign language students, suggest that students studying Latin outperform modern foreign language students. No studies have been conducted on the precise impact of learning Latin on MFL acquisition of native English speakers, however, and further research into this area is required. One study on the subject exists; however, it assesses German rather than English native speakers. Haag and Stern (2003) tested German L1 speakers with regard to the preparation for Spanish study through Latin or French. Those German speakers who had studied French outperformed the Latin students. The impact of Latin learning on MFL development is thus not a claim which can currently be substantiated.

Finally, regarding cognitive transfer, the evidence is again less persuasive. Only two studies - Sheridan (1976) and Masciantonio (1979: 377) - acknowledge mathematical improvements alongside linguistic development among Latin learners. Recent negative findings, conversely, conveyed by Carlisle and Liberman (1989: 17991) and Carlisle (1993: 339-53), have been attributed explicitly to the lack of transferability of Latin skills to other subject areas. Haag and Stern (2003: 175) argue that transfer of knowledge depends on the pupils' ability to detach specific activities from their context, which may not be present in every pedagogic approach. A modern UK study, discussed by Woolcock (2016) may provide more methodological evidence for transfer of Latin skills to mathematics.

\section{Latin and English native speakers}

On the whole, the findings of the existing studies provide the strongest case for the near transfer of Latin study to native language (L1) development, particularly vocabulary and comprehension. This needs to be contextualized in current understanding about 
language learning, however. Evidence concerning the positive influence of foreign language (L2) learning on L1 proficiency - coined 'multicompetence' by Cook (1991) is, indeed, still disputed. First, the Critical Period Hypothesis $(\mathrm{CPH})$, which argues that L2 learning should start as early as possible, has largely been discredited, as Hunt et al. (2005: 371-372) maintain. Second, current research on modern foreign language (MFL) learning suggests that there are many complex conditions which need to be fulfilled for successful linguistic progress to take place, such as - among others - social, process, and individual/group factors (Johnstone (2003)), availability of resources and infrastructure (Powell (2001)) and teacher training (Burstall et al. (1974)). A recent study by Murphy et al. (2015: 1134) highlights disparities between test findings regarding the impact of L2 learning on L1 proficiency, which range from highly beneficial to detrimental - though Murphy et al.'s own test (2015: 1139-1151) demonstrates a positive impact of French and Italian learning on English aptitude. There is thus some evidence concerning the impact of L2 on L1 proficiency which supports the findings concerning Latin.

The reason for the significant impact of Latin learning on L1 development is still unclear. It might be explained by Murphy et al. (2015), who argue that the beneficial impact of L2 on L1 learning is greater when L2 is a language with high graphemephoneme correspondence (GPC). This confirms the findings which suggest that Latin learning has the potential of bringing more benefit to primary language learners than modern European languages. Another reason might be the particular pedagogy: in many of the studies mentioned above, a multisensory approach focusing directly on orthography, phonology, and syntax was applied in Latin study (e.g. Sparks et al. (1996)). Among pupils who had hitherto not been taught grammar, a direct confrontation with such concepts might indeed lead to improvements in those areas. 
While researchers have posited such reasons for the impact of Latin on L1 learning, these are deductions and cannot be generalized, as the existence of tests which report no differences between Latin learners and control groups. Latin itself, it seems, is thus not sufficient: certain conditions - whether social, pedagogic, or other - must be present for Latin instruction to have an impact on L1 which outstrips that of control groups.

\section{Contextualization}

It is not just the methodology which must be reviewed to assess accurately the value of the existing studies. With just over a century of evidence and more than 17,000 participants tested, it is important to contextualise the studies' historical and geographical background. Graph I (INSERT Figure I) highlights two chronological peaks of studies: first in the 1910s-1920s, and then again between the 1960s-1980s; the main gap corresponds to WWII and its aftermath. A second graph (INSERT Figure II) demonstrates the strong correlation between the decade during which tests were conducted and the results. In the early testing period, the results - drawn from high schools alone, as Latin was not part of the elementary curriculum - were almost exclusively negative. In the second period, conversely, results regarding the impact of Latin on L1 progress were predominantly positive. If one considers the results from the two periods together, $63 \%$ of studies found Latin instruction has a positive impact on pupils, $10.8 \%$ a negative impact, and $26 \%$ was inconclusive. When one considers only the results from the 1960 s onwards, there is a significant shift, and indeed the elementary school data produced more significant positive results than those from high schools: $86 \%$ of the elementary results were positive versus $75 \%$ of high school data. A number of factors have been put forward to account for this chronological discrepancy. 
In the antebellum and interbellum periods, Latin was an established and conservative part of the US grammar-school curriculum preparing middle and upper class young men for university. ${ }^{10}$ Pedagogy was founded on the principles of the traditional grammar-translation approach. Fear of failure, anxiety and even lack of interest in what is compulsory often creates a high affective filter between pupil and study ${ }^{11}$ and Latin may be a case in point.

From the 1960s onwards, while the grammar-translation pedagogy continued to hold sway in traditional backgrounds, Latin was also brought to deprived inner-city children in both elementary and high schools. This approach incorporated the abovementioned oral-aural approach, for example, rather than the traditional grammartranslation approach ${ }^{12}$ and was strongly founded on left-wing principles, as can be gleaned from a lesson extract in Rudolf Masciantonio's humanistic course book How the Romans lived and spoke (1970):

\begin{abstract}
Ask how many children have ever heard of BLACK POWER. Ask the same question about WHITE POWER and FLOWER POWER. Tell them that Latin gives them a power which is greater in many ways than all three put together, viz. WORD POWER. Say WORD POWER in a loud voice and have the children repeat it. Tell them that Latin words are like sticks of dynamite. Every time you learn one Latin word it explodes into many English words. Breaking up some chalk into small pieces and letting the chalk scatter when you say the work "explodes" is an effective dramatic device at this point. ${ }^{13}$
\end{abstract}

The correlation between Latin teaching and movements such as the Civil Rights Movement and Flower Power is a clear demonstration of the ethos of 1960s-1980s Latin teachers in the US. Masciantonio (1977: 382) indeed attributes the more positive results of the 1960s-1980s studies to their innovative teaching styles, as he considers the grammar-translation method outdated and counter-productive. 
When considering the geographical spread of the 1960 s to 1980 s testing, Figure III (INSERT Figure III) reveals that studies are largely centred on the East coast of the US, alongside California in the West. ${ }^{14}$ The North East coast is historically more European-focused and intellectually liberal - and California, in its own way, is quite similar, as argued by Gottmann (1961: 45) - so it should come as no surprise that pedagogic innovation was driven by these regions.

Considered together, the chronological and geographical discrepancies suggest that in the 1960s-1980s, results were affected positively by changes to the teaching approach in particular social strata in the US. It is possible that taking part in innovative studies which were undoubtedly promoted strongly and taught by dedicated teachers increased the positive effect on the pupils, while conversely, as Smith (2007: 119) argues, disengaged teachers and/or a traditional pedagogy might have an adverse effect on learning. This demonstrates that teaching engagement and a more pupil-led pedagogy has a clear impact in comparison with a traditional teacher-led teaching style.

After the 1980s, however, findings from nationwide studies comparing SAT (Scholastic Assessment Test) results of Latin students with those of Modern Foreign Language students - often used to demonstrate the comparative success of Latin students ${ }^{15}$ - are less persuasive: ${ }^{16}$ though they demonstrate an advance of Latin students over MFL students, they do not differentiate regarding the social background of students: while Latin has been introduced in deprived areas as well, current Latin high school students are still largely from an affluent background. Hence Latin - while it may have had an impact - may not be the (only) decisive factor of their success, and further research is required. ${ }^{17}$ 


\section{Absent data}

Considering the post-1960s studies, the evidence regarding Latin impact on L1 has been largely positive. The switch from predominantly negative results to predominantly positive results between the 1910 s and 1980s appears to be linked to the shift from grammar-translation to reading method and Direct Response pedagogy as well as the different place of Latin in the curriculum, which corroborates Masciantonio's (1977: 382) argument concerning the impact of pedagogic approach. ${ }^{18}$ Moreover, negative data often correlate with affluent areas and intellectual background with a greater likelihood of constructive pedagogic home input, which suggests that socio-economic background matters in learning and Latin can have a greater impact on deprived areas. ${ }^{19}$

There are, however, also important absent data. First, in most studies - for example in Douglass and Kittelson (1935: 28) and Holmes and Keffer (1995: 48) - a socio-economic spread of participants is mentioned without detailing how each stratum performed separately. While some studies mention a pedagogic approach, this is absent from most. And finally, while Masciantonio's course book refers to Black Power and Flower Power, data on race and gender are conspicuously absent from all of the studies.

\section{Data for the future}

In gathering this evidence, we have aimed to explore to what extent the historical US data provide significant evidence for the beneficial impact of learning Latin. Our review has demonstrated that the majority of findings support the claim that Latin helps with vocabulary, comprehension, and reading development of English L1 pupils, even more so at primary than at secondary school. The specific impact on special educational needs pupils and socio-economically challenging areas is particularly noteworthy. Nevertheless, the two other claims regarding the transfer of Latin study - on MFL study 
and cognitive development - cannot be substantiated significantly and require further research.

The question remains whether the findings from the past century can still be applied without hesitation to current Latin pedagogy. While this article does not wish to take away from the achievements of the teachers and researchers who undertook the laborious task of conducting the various tests, it must be acknowledged that any other academic field which would still rely on findings from more than ten years ago as its main body of evidence would be considered outdated. New research is therefore necessary, not only because educational contexts have changed, but also methodologies. Most of the tests conducted in the past century lacked a distinct methodology, and were instead based on ideological assumptions, some already presupposed by Classicists. While the existing findings can form a solid basis, they cannot be used as quod erat demonstrandum, but rather as a starting point for new research with modern methodologies. Two European studies point the way: Haag and Stern (2003) and the study outlined by Woolcock (2015). The clear methodologies need to be applied to future research regarding the impact of Latin.

One finding visible in a large proportion of the tests we have reviewed, however, is that Latin learning has a more positive impact in deprived areas than in average and affluent areas. Similarly to 1960 s US, Latin has been already been introduced in deprived areas in the UK with an innovative pedagogic approach. Several on-going projects - such as in London, Norfolk, Glasgow and Swansea ${ }^{20}$ - solicit comparative study. In further research, factors such as gender, social background, ability and teaching approach can now be integrated further. One might also pose the question why primary Latin instruction is more beneficial for L1 development than secondary school instruction. These factors must play a major role in twenty-first century Latin learning. 
Finally, it must also be acknowledged that quantitative data only provide limited information, and learning Latin can be about much more than just language. While there is significant evidence for the impact of Latin learning on L1 development, it is also clear that just Latin is not sufficient, and other factors - from pedagogic to pastoral must be present. Qualitative data collated in studies such as Wilhelm and Wilhelm (1991: 13-16), Harrington-Lueker (1992: 21-25), Sienkewicz (2004: 301-12) and Smith (2007) demonstrate tangible improvements in quality of life of pupils studying Latin, from confidence to global awareness and cultural appreciation. In an education system preoccupied with data, the clear aim that pupils should enjoy this learning must remain paramount. $^{21}$

\section{Funding}

This work was supported by the British Academy/Leverhulme Trust [grant number SG141257].

\section{Supplemental data}

Appendix 1: Chronological list of US studies (X means data are missing)

\begin{tabular}{|l|l|l|l|l|l|}
\hline Area & Documented by & Year & $\begin{array}{l}\text { Number of } \\
\text { students }\end{array}$ & $\begin{array}{l}\text { Elementary/ } \\
\text { high school }\end{array}$ & $\begin{array}{l}\text { Amount of Latin } \\
\text { instruction }\end{array}$ \\
\hline Massachusetts & Barber 1986-'87 & 1914 & 42 & HS & 2 years \\
\hline US & Harris 1915 & X & X & HS & 3 years \\
\hline US & Foster 1915 & X & X & HS & X \\
\hline US & Dallam 1917 & X & X & HS & X \\
\hline US & Orleans 1922 & X & X & HS & X \\
\hline New York & Otis 1922 & 1921 & 84 & HS & X \\
\hline US & Kirby 1923 & X & X & HS & X \\
\hline US & $\begin{array}{l}\text { Thorndike and Ruger } \\
1923\end{array}$ & X & X & HS & 1 year \\
\hline US & Gilliland 1922 & X & X & HS & X \\
\hline US & $\begin{array}{l}\text { Miller and Briggs } \\
1923\end{array}$ & $\mathrm{X}$ & $\mathrm{X}$ & HS & X \\
\hline US & Thorndike 1924 & 1922 & 8,500 & HS & 1 year \\
\hline US & Coxe 1924 & $\mathrm{X}$ & 58 schools & HS & 1 year \\
\hline US & Hamblen 1925 & $\mathrm{X}$ & $\mathrm{X}$ & HS & X \\
\hline US & Clark 1932 & $\mathrm{X}$ & $\mathrm{X}$ & HS & X \\
\hline US & Douglass & $\mathrm{X}$ & $\mathrm{X}$ & HS & X \\
\hline
\end{tabular}




\begin{tabular}{|c|c|c|c|c|c|}
\hline & Kittelson 1935 & & & & \\
\hline US & Pond 1938 & $\mathrm{X}$ & 208 & HS & $1-5$ semesters \\
\hline US & Josephina 1963 & $\mathrm{X}$ & 209 & HS & 7 months \\
\hline Washington & LeBovit 1967 & 1966 & 600 & ES & 20 minutes weekly \\
\hline Washington & LeBovit 1967 & 1966 & 258 & HS & 20 minutes weekly \\
\hline $\begin{array}{l}\text { Erie country, } \\
\text { Pennsylvania }\end{array}$ & Masciantonio 1977 & 1969 & 352 & $\mathrm{ES}$ & $\mathrm{X}$ \\
\hline Columbia & Masciantonio 1977 & $\begin{array}{l}1970- \\
71\end{array}$ & 132 & ES & $\mathrm{X}$ \\
\hline Washington DC & Cederstrom 1974 & $\mathrm{X}$ & $\mathrm{X}$ & ES & 8 months \\
\hline Easthampton & $C W 68,1975$ & 1973 & 250 & ES & $\begin{array}{l}20 \text { minutes three } \\
\text { times a week }\end{array}$ \\
\hline Philadelphia & Masciantonio 1977 & $\begin{array}{l}1971- \\
1975\end{array}$ & 14,000 & $\mathrm{ES}$ & 20-minutes a day \\
\hline Alexandria VA. & Masciantonio 1977 & $\begin{array}{l}1972- \\
1974\end{array}$ & $\mathrm{X}$ & $\mathrm{ES}$ & $\mathrm{X}$ \\
\hline Boston & Bowker 1975 & 1974 & $\mathrm{X}$ & HS & 2 years \\
\hline Indianapolis & Sheridan 1975 & $\begin{array}{l}1973- \\
1976\end{array}$ & 400 & ES & 30 minutes daily \\
\hline Washington & $\begin{array}{l}\text { Human engineering } \\
\text { laboratory, } 1974\end{array}$ & 1973 & 220 & $\mathrm{ES}$ & $\mathrm{X}$ \\
\hline Los Angeles & Masciantonio 1977 & $\begin{array}{l}1975- \\
1976\end{array}$ & $\mathrm{X}$ & $\mathrm{ES}$ & 20 minutes daily \\
\hline Los Angeles & Sussman 1978 & $\begin{array}{l}1975- \\
1976\end{array}$ & $\mathrm{X}$ & ES & $\begin{array}{l}45 \text { minutes } 3 \text { times } \\
\text { a week }\end{array}$ \\
\hline Worcester & Masciantonio 1977 & 1975 & $\mathrm{X}$ & HS & 5 times a week \\
\hline California & Sussman 1978 & $\begin{array}{l}1975- \\
1976\end{array}$ & $\mathrm{X}$ & ES & $\begin{array}{l}45 \text { minutes } 3 \text { times } \\
\text { a week }\end{array}$ \\
\hline $\begin{array}{l}\text { Educational } \\
\text { testing service }\end{array}$ & LaFleur 1981 & $\begin{array}{l}1979- \\
1980\end{array}$ & $\mathrm{X}$ & HS & $\mathrm{X}$ \\
\hline Brooklyn & Fromchuck 1984 & 1981 & 120 & ES & $\begin{array}{ll}45 \text { hours in } 8 \\
\text { months }\end{array}$ \\
\hline US & Offenberg 1982 & $\begin{array}{l}1980- \\
1981 \\
\end{array}$ & 60 & HS & $\mathrm{X}$ \\
\hline New York & Polsky 1986 & $\begin{array}{l}1982- \\
1984 \\
\end{array}$ & $\mathrm{X}$ & ES & $\mathrm{X}$ \\
\hline Tennessee & Wiley 1985 & 1983 & 306 & $\mathrm{HS}$ & $\mathrm{X}$ \\
\hline US & Reinhardt 1984 & 1983 & $\mathrm{X}$ & $\mathrm{HS}$ & $\mathrm{X}$ \\
\hline East Carolina & Bassman 1984 & 1983 & 30 & ES & $\begin{array}{l}\text { twice } 30 \text { minutes a } \\
\text { week }\end{array}$ \\
\hline US & LaFleur 1985 & $\mathrm{X}$ & $\mathrm{X}$ & $\mathrm{HS}$ & $\mathrm{X}$ \\
\hline $\mathrm{X}$ & Townsley 1985 & $\mathrm{X}$ & $X$ & $\mathrm{HS}$ & One semester \\
\hline US & Morgan 1989 & 1987 & $\mathrm{X}$ & $\mathrm{HS}$ & $\mathrm{X}$ \\
\hline US & $\begin{array}{ll}\text { VanTassel } & \text { Baska } \\
1987 & \end{array}$ & $\mathrm{X}$ & $\mathrm{X}$ & HS & 1 year \\
\hline US & $\begin{array}{ll}\text { Carlisle } & \text { and } \\
\text { Liberman } 1989 & \\
\end{array}$ & 1988 & 30 & HS & 2 years \\
\hline Cincinatti & Sparks 1996 & 1995 & 27 & $\mathrm{HS}$ & $\mathrm{X}$ \\
\hline US & Carlisle 1993 & $\mathrm{X}$ & $\mathrm{X}$ & HS & $\mathrm{X}$ \\
\hline Georgia & $\begin{array}{l}\text { Holmes \& Keffer } \\
1996\end{array}$ & 1995 & 115 & HS & $\begin{array}{l}\text { twice } 45 \text { minutes a } \\
\text { week for } 8 \text { weeks }\end{array}$ \\
\hline $\mathrm{X}$ & Prager 2000 & $\mathrm{X}$ & $\mathrm{X}$ & $\mathrm{HS}$ & 2 years \\
\hline Nuremberg, & Haag and Stern 2003 & $\mathrm{X}$ & 115 & University & $\mathrm{X}$ \\
\hline
\end{tabular}




\begin{tabular}{|l|l|l|l|l|l|}
\hline Germany & & & & & \\
\hline National & Bolchazy-Garducci & $\begin{array}{l}2011- \\
2012\end{array}$ & $\mathrm{X}$ & HS & $\mathrm{X}$ \\
\hline
\end{tabular}

\section{References}

Comments on some current vocabulary research. Bulletin 115 (Human Engineering Laboratory).

1975. Latin for fifth and sixth graders in Easthampton, Massachusetts. Classical World 68: 444.

Ashe, A. 1998. Latin for Special Needs Students: Meeting the challenge of students with learning disabilities. In ed. LaFleur, 237-50.

Barber, G. 1985-1986. Latin as a practical study. Classical Journal 81, no. 2: 158-60.

Bassman, M. and M. Ironsmith. 1984. An experimental FLES program in Latin. ADFL Bulletin 16: 41 .

Board, K. and T. Tinsley. 2015. Language trends 2014/15: the state of language learning in primary and secondary schools in England. CfBT Education Trust. http://cdn.cfbt.com/ /media/cfbtcorporate/files/research/2015/r-language-trends-2015.pdf (accessed 20 January, 2017).

Bowker, R. 1975. English vocabulary comparison of Latin and non-Latin students. Technical Report 831 (Boston, Massachusetts).

Bolchazy-Garducci Publishers. 2012. Study of Latin bolsters achievement tests scores. http://www.bolchazy.com (accessed 21 January, 2017).

Bracke, E. 2016a. The role of university students in increasing Widening Participation to Classics. Journal of Widening Participation and Lifelong Learning 18.2: 111-29.

Bracke, E. 2016b. Battle of the gods: Welsh days of teh week between the Roman, Germanic, and Christian traditions. http://swwclassicalassociation.weebly.com/secretarysblog/-battle-of-the-gods-welsh-days-of-the-week-between-the-roman-germanicand-christian-traditions (accessed 21 January, 2017).

Burstall, C. 1974. Primary French in the balance. Windsor UK: NFER. 
Butterworth, L. 2016. Aequora: Teaching Literacy with Latin. Eidolon, 5 December 2016. https://eidolon.pub/aequora-8accc39de16c\#.75mjg8vnf (accessed 21 January, 2017).

Carlisle, J. and I. Liberman. 1989. Does the study of Latin affect Latin proficiency?. Reading and Writing 1: 179-91.

Carlisle, J. 1993. The influence of study of a second language on improvement in spelling. Reading and Writing 5: 339-53.

Cederstrom, E. 1974. Quid agunt discipuli? Latin in Philadelphia. Independent School Bulletin 33: 56-57.

Chanock, K. 2006. Help for a dyslexic learner from an unlikely source. Literacy 40: 164-70.

Clark, E. 1932. Amount of high school Latin as an indicator of success in college work. School and Society 35: 189-190.

Colligan, I. 1944. Pragmatists and high school Latin. Manuscripts 12: 13-15.

Cook, V. 1991. Second Language Learning and Language Learning. London: Edward Arnold.

Cook, V. (ed.) 2003. Effects of the second language on the first. Clevedon: Multilingual Matters.

Coulmas, F. 1989. Writing Systems of the World. Oxford: Blackwell.

Dallam, M. 1917. Is the study of Latin advantageous to the study of English?. Educational Review 54: 500-503.

DeVane, A. 1997. Efficacy of Latin Studies in the Information Age. http://teach.valdosta.edu/whuitt/files/latin.html (accessed 20 January, 2017).

Douglass, H. and C. Kittelson. 1935. The transfer of training in high school Latin to English grammar, spelling and vocabulary. Journal of Experimental Education 4: 26-33.

Foster, E. 1917. The results of a recent spelling test at the University of Iowa. School and Society 5: 506-508.

Fromchuck, A. 1984. The Measurable Benefits of Teaching English through Latin in Elementary School. Classical World 78: 25-29.

Gilliland, A. 1922. Effect of the study of Latin on ability to define words. Journal of Educational Psychology 13: 501-06. 
Gottmann, J. 1961. Megalopolis: The Urbanized Northeastern Seaboard of the United States. New York: Twentieth Century Fund.

Gruber-Miller, J. 2006. When Dead Tongues Speak: Teaching Beginning Greek and Latin. Oxford and New York: American Philological Association.

Haag, L. and E. Stern. 2003. In search of the benefits of learning Latin. Journal of Educational Psychology 95, no. 1: 174-178.

Hamblen, A. 1925. An investigation to determine the extent to which the effect of the study of Latin upon a knowledge of English derivatives can be increased by conscious adaptation of content and method to the attainment of this objective. Philadelphia PA: University of Pennsylvania.

Harrington-Lueker, D. 1992. Latin redux. Executive Educator 14, no. 8: 21-25.

Harris, L. 1915. A study in the relation of Latin to English composition. School and Society 2: 251-252.

Hill, B. 2006. Latin for students with severe foreign language learning difficulties. In ed. J. Gruber-Miller, 50-67.

Holmes, C. and R. Keffer. 1995. A computerized method to teach Latin and Greek root words: Effect on verbal SAT scores. Journal of Educational Research 89: 50.

Hubbard, T. 2003. Special needs in Classics. In ed. J. Morwood. The Teaching of Classics. Cambridge, 51-60.

Hunt, M., A. Barnes, B. Powell, G. Lindsay and D. Muijs. 2005. Primary modern foreign languages: an overview of recent research, key issues and challenges for educational policy and practice. Research Papers in Education 20, no. 4: 371-390.

John Jerrim. 2011. England's 'plummeting' PISA test scores between 2000 and 2009: is the performance of our secondary school pupils really in relative decline?. https://www.ioe.ac.uk/Study_Departments/J_Jerrim_qsswp1109.pdf (accessed 20 January, 2017).

Johnstone, R. 2001. Languages at primary school as a matter of national and international policy. What can research tell us about the key conditions for success. Paper presented at 
CUP/BAAL seminar on Young Language Learners, University of Manchester. 15 June 2001.

Johnstone, R. 2003. Progression. Paper presented at CILT ITT conference Enabling Change. Cambridge. 6 September 2003.

Josephina, S. 1963. Latin: an effective word builder. Classical Journal 58: 354-55.

Kirby, T. 1923. Latin as a Preparation for French. School and Society 18: 563-569.

Knapp, C. 1922. Tests and measurements in Latin. Classical World 15, no. 20: 153-157.

Koutropoulos, A. 2011. Modernizing Classical language education: Communicative Language Teaching and educational technology integration in Classical Greek. Human Architecture 9, no. 3: 55-70.

Krashen, S. and T. Terrell. 1983. The Natural Approach: Language Acquisition in the Classroom. Hayward CA: Prentice Hall Europe.

LaFleur, R. 1981. Latin students score high on SAT and achievement tests. Classical Journal 76: 254 .

LaFleur, R. 1985. 1981 SAT and Latin achievement test results and enrolment data. Classical Journal 77: 343 .

LaFleur, R. 1998. Latin for the $21^{\text {st }}$ Century: From Concept to Classroom. Glenview IL: Addison Wesley.

LeBovit, J. 1967. Qui timide rogat, docet negare. Classical World 61, no. 2: 37-40.

Lister, B. 2007. Changing Classics in Schools. Cambridge: Cambridge University Press.

Livingstone, J. 2013. Why you should learn a dead language. The Guardian 16 September 2013. https://www.theguardian.com/education/2013/sep/16/why-learn-a-dead-language (accessed 20 January, 2017).

Masciantonio, R. 1970. How the Romans Lived and Spoke (Teachers' Guide). Philadelphia: Instructional Services. http://files.eric.ed.gov/fulltext/ED044066.pdf (accessed 20 January, 2017).

Masciantonio, R. 1977. Tangible benefits of the study of Latin: a review of research. Foreign Language Annals 10: 375-382. 
Mavrogenes, N. 1977. The effect of elementary Latin instruction on language arts performance. Elementary School Journal 77: 268-273.

Miller, G. and T. Briggs. 1923. The effect of Latin translations on English. School Review 31: 756-762.

Morgan, L. and C. Pelling. 2010. Latin for Language Learners: Opening Opportunities for Primary Pupils. http://www.politeia.co.uk/p116.pdf (accessed 20 January, 2017).

Morgan, R. 1989. An examination of the relationship of academic course work with admissions test performance. College Board Report 89-6: 13.

Murphy, V., E. Macaro, S. Alba and C. Cipolla. 2015. The influence of learning a second language in primary school on developing first language literacy skills. Applied Psycholinguistics 36: 1133-1153.

Omrani, B. 2010. Teaching Latin at primary school level (Durand Primary School). http://www.bijanomrani.com/?p=teachingLatin (accessed 20 January, 2017).

Offenberg, R. 1982. Language Arts through Latin. Philadelphia (Office of Research and Evaluation).

Orleans, J. 1922. Possible transfer value of the study of Latin to English vocabulary. School and Society 16: 559-560.

Otis, A. 1922. The relation of Latin study to ability in English vocabulary and composition. School Review 30, no. 1: 45-50.

Polsky, M. 1986. The NEH/Brooklyn College Latin Cornerstone Project, 1982-84: Genesis, implementation, evaluation. Classical Outlook 63: 77-83.

Pond, F. 1938. Influence of the study of Latin on word knowledge. School Review 46, no. 8: 611-618.

Pouzin, H. 1983. Le latin. Pour quoi le faire? Paris: Téqui.

Powell, B., D. Wray, S. Rixon, J. Medwell, A. Barnes and M. Hunt. 2001. Analysis and evaluation of the current situation relating to the teaching of Modern Foreign Languages at Key Stage 2 in England (QCA). http://www.qca.org.uk/ca/subjects/mfl/warwick.pdf (accessed 20 January, 2017). 
Prager, R. 2000. Introductory language: opening new doors. Middle School Journal 31, no. 4: 29-33.

Rasinski, T., N. Padak, J. Newton, E. Newton. 2011. The Latin-Greek connection. The Reading Teacher 65: 133-141.

Reinhardt, E. 1983. They don’t call this class ‘bor-ing'. English Journal 72: 37.

Richard, C. 2009. The Golden Age of the Classics in America: Greece, Rome, and the antebellum United States. Cambridge MASS.: Harvard University Press.

Riess, W. and C. Riess. 2005. The state of Latin instruction in Germany today. Classical Journal 101, no. 2: 191-199.

Sebesta, J. 1998. Aliquid semper novi: new challenges, new approaches. In ed. LaFleur, 15-24.

Sheridan, R. 1976. Augmenting reading skills through language learning transfer, FLES Latin Programme Evaluation Reports. Indianapolis: Indianapolis Public Schools.

Sienkewicz, T. et al. 2004. Lingua latina liberis: four models of Latin in the elementary school. Classical Journal 99, no. 3: 301-312.

Simpson, J. 2014. What's the state of the evidence on... Latin?. https://secondarysource.wordpress.com/2014/10/03/whats-the-state-of-the-evidence-onteaching-latin/ (accessed 20 January, 2017).

Smith, J. 2007. The correlation of Latin, Greek and the Classical Education model with learning other subjects. $\mathrm{PhD}$ diss., Capella University.

Sparks, R., L. Ganschow, K. Fluharty and S. Little. 1996. An exploratory study on the effects of Latin on native language skills and foreign language aptitude of students with and without learning disabilities. Classical Journal 91: 165-184.

Stead, H. and E. Hall. 2015. Greek and Roman Classics in the British Struggle for Social Reform. London: Bloomsbury.

Sussman, L. 1978. The decline of basic skills: a suggestion so old that it's new. Classical Journal 73: 351 .

Thorndike, E. 1924. Mental discipline in school studies. Journal of Educational Psychology 15: $1-98$. 
Thorndike, E. and G. Ruger. 1923. The effect of first-year Latin upon knowledge of English words of Latin derivation. School and Society 18: 4.

Townsley, L. 1985. Latin as a vocabulary builder for hearing-impaired and second-language students of English. Teaching English to Deaf and Second-Language Students 3: 4-8.

VanTassel-Baska, J. 1987. A case for the teaching of Latin to the verbally talented. Roeper Review 9: 159-161.

Wiley, P. 1984-1985. High school foreign language study and college academic performance. Classical Outlook 62, no. 2: 33-36.

Wilhelm, M. and R. Wilhelm. 1991. Bringing the Classics to life. Humanities 12, no. 1: 13-16.

Wolverton, R. 1975. Classics for the future. Paper presented at the Classical Association of the Atlantic States Conference, in his presidential address of the Classical Association of the Atlantic States, 15 November 1975 in Atlantic City NJ. http://0files.eric.ed.gov.opac.msmc.edu/fulltext/ED113976.pdf (accessed 20 January, 2017).

Woolcock, N. 2015. Bite-sized Greek and Latin lessons boost reading and maths skills. The Times, 28 December 2015. http://www.thetimes.co.uk/tto/education/article4650548.ece (accessed 20 January, 2017).

Young, T. 2011. Forget Mandarin: Latin is the key to success. The Spectator, 3 February 2011. http://blogs.spectator.co.uk/2011/02/forget-mandarin-latin-is-the-key-to-success/ (accesed 20 January, 2017).

\footnotetext{
Footnotes

${ }^{1}$ See e.g. Stead and Hall (2015) for a discussion of Classics in British ideology.

${ }^{2}$ See Colligan (1944) for a good example of circumstantial evidence for the benefits of learning Latin.

${ }^{3}$ See Bracke (2016b), for example, on the names of the days of the week in Welsh, which correspond to Latin more than those of Romance languages.

${ }^{4}$ Various research projects are currently ongoing in the UK, and findings are expected to be published in the next few years.

${ }^{5}$ This is mentioned by R. Wolverton in his presidential address of the Classical Association of the Atlantic States in 1975, 'Classics for the future': <http://0files.eric.ed.gov.opac.msmc.edu/fulltext/ED113976.pdf>, accessed 20 October 2015.

${ }^{6}$ Butterworth (2016), Young (2011), and Morgan and Pelling (2010).
} 
${ }^{7}$ Six articles have reviewed evidence, though in a cursory manner with incomplete information: Omrani (2010); DeVane (1997); Masciantonio (1977: 375-82); Mavrogenes (1977: 268-73); Pond (1938: 611-18); and C. K. (1922: 153-7).

${ }^{8}$ See Smith (2007) for a comprehensive discussion.

${ }^{9}$ See also Hubbard (2003) and Chanock (2006) for further discussion.

${ }^{10}$ Richard (2009: 1-40).

${ }^{11}$ This is an emotional barrier, documented by Krashen and Terrell (1983: 39).

${ }^{12}$ For a summary of the development, see Sebesta (1998: 15-24).

${ }^{13}$ Capital letters by Masciantonio.

${ }^{14}$ Of the fifty tests done in the US, twenty-three are either concerned with national data on SAT results or offer no details regarding location (mostly in the pre-1960s tests). The other twenty-two give specific details about their location. This number is significant enough to discern a trend.

${ }^{15}$ E.g. Bolchazy-Garducci Publisher (2012).

${ }^{16}$ E.g. LaFleur (1981: 254); Townsley (1985: 4-8); Morgan (1989: 13); Holmes and Keffer (1995: 50). The most recent study is Bolchazy-Garducci (2012).

${ }^{17}$ Simpson (2014). See also Foster (1917: 506-8); Thorndike (1924: 1-98); and Douglass and Kittelson (1935: 26-33).

${ }^{18}$ Also see Bassman and Ironsmith (1984: 41). A similar argument has been made for the teaching of ancient Greek; see Koutropoulos (2011).

${ }^{19}$ This is particularly apparently in the studies in Washington, Columbia and New York, all reported by Mavrogenes (1977).

${ }^{20}$ London: BSix East End Classics Centre (http://www.capitalclassics.org.uk/); Norfolk: Primary Latin Project (http://www.itv.com/news/anglia/2013-11-22/how-latin-is-makingsomething-of-a-comeback-in-norfolk-schools/; accessed 20 October 2015); Glasgow (http://www.heraldscotland.com/news/13108844.Latin_makes_comeback_in_schools/; accessed 20 October 2015) and Swansea (http://www.literacythroughclassics.weebly.com).

${ }^{21}$ See Bracke (2016a) for such evidence regarding the Literacy through Classics project at Swansea University. 
The impact of learning Latin on school pupils:

Maps/graphs to be inserted into article:

Figure I

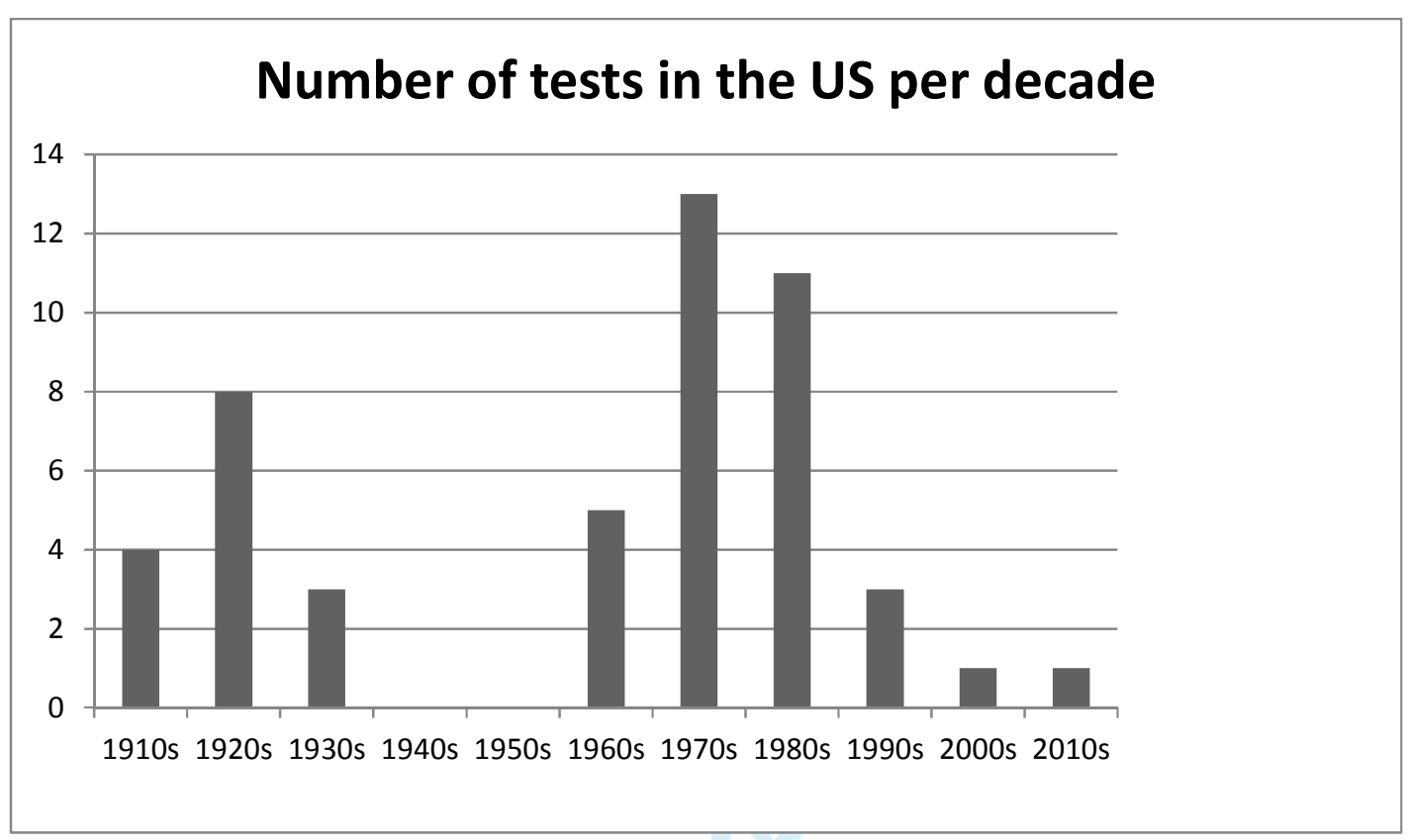

URL: http://mc.manuscriptcentral.com/rllj Email: N.Pachler@ioe.ac.uk 
The impact of learning Latin on school pupils:

Maps/graphs to be inserted into article:

Figure II

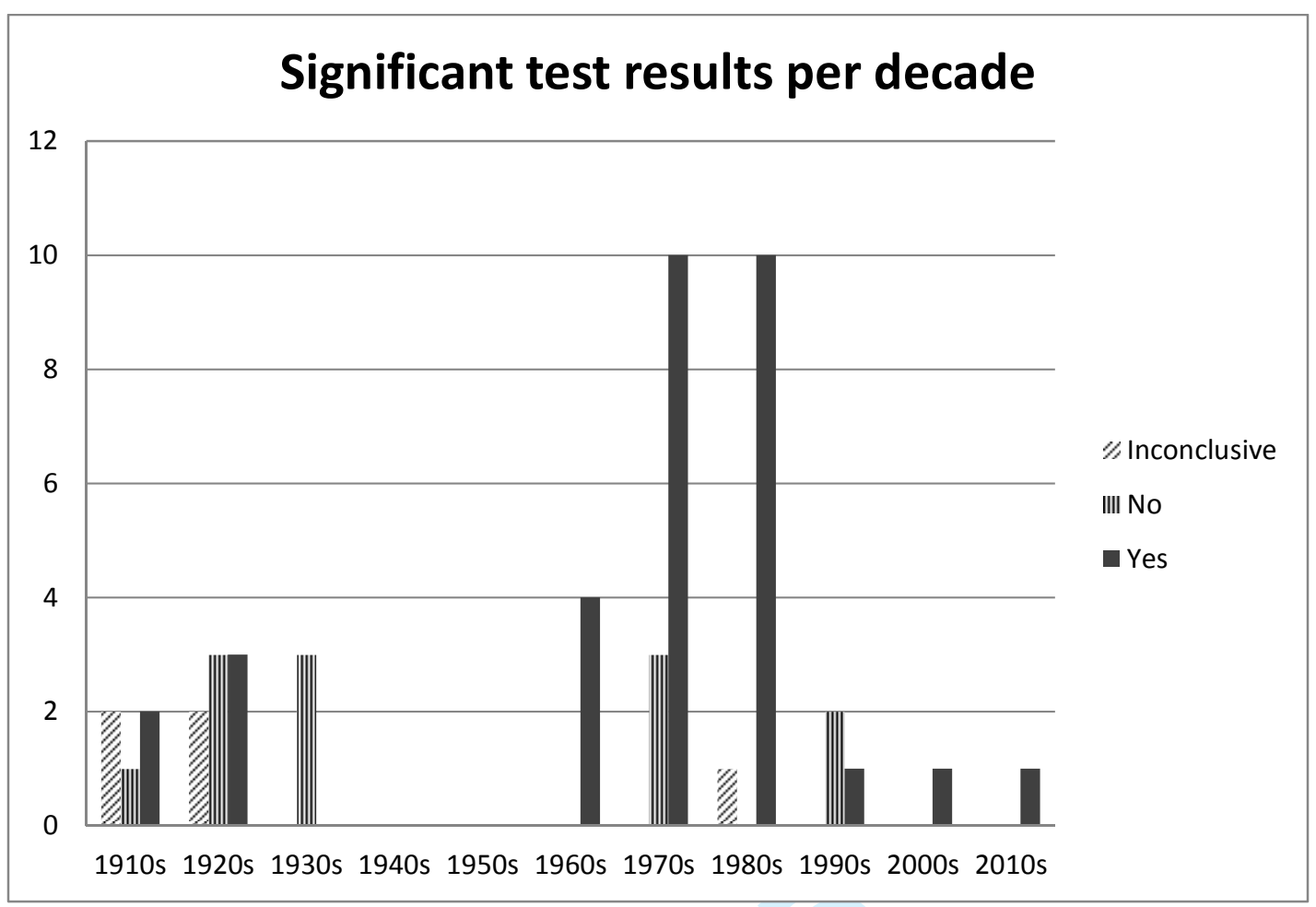

URL: http://mc.manuscriptcentral.com/rllj Email: N.Pachler@ioe.ac.uk 
The impact of learning Latin on school pupils:

Maps/graphs to be inserted into article:

Figure III

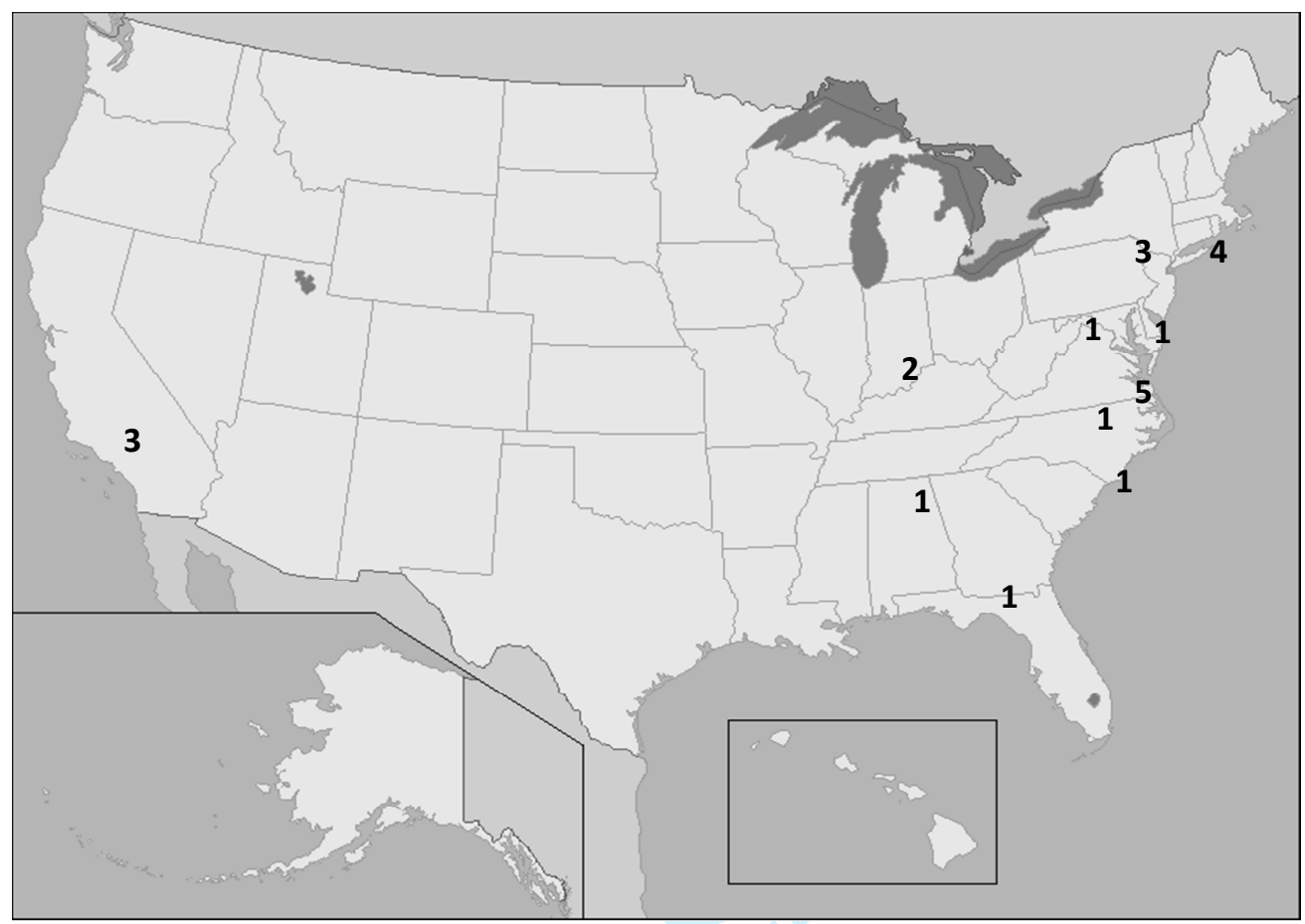

34

35

36

37

38

39

40 